\title{
PENGEMBANGAN DAYA TARIK WISATA DI AGROWISATA BALAI BENIH INDUK LUBUK MINTURUN PADANG
}

\author{
Yuliana $^{1}$, Heru Pramudia ${ }^{1}$, Nilma Lova Utami ${ }^{2}$ \\ ${ }^{1}$ Dosen Fakultas Pariwisata dan Perhotelan \\ ${ }^{2}$ Alumni Fakultas Pariwisata dan Perhotelan \\ Universitas Negeri Padang \\ Email: yuliana@fpp.unp.ac.id
}

\begin{abstract}
This research was motivated by the lack of tourist attraction in Agrowisata Balai Benih Induk (BBI) of Lubuk Minturun Padang, such as, there is no entertainment and recreation services at agro rides $B B I$, the least of the event activities in agrotourism meeting room BBI and the lack of souvenirs offered by agro tourism BBI Lubuk Minturun Padang. This research aims to determine the strategy of developing tourist attraction that has indicators in the form of tourist attractions, amenities and anchillary services are viewed from internal factors in the form of strengths and weaknesses and external factors in the form of opportunities and threats. This research is a descriptive research with qualitative data. Data collection technique is done by interview and observation that involves informant by using purposive sampling and snowball sampling technique. Development strategy of tourist attraction that can be done is in the form of: 1) Optimizing the function of land by developing tourism activities such as providing rides games and mini garden. 2) Develop MICE event in meeting and gazebo sessions such as holding workshops and agricultural exhibition. 3) Provide souvenirs by utilizing culture and network techniques.
\end{abstract}

Keyword: strategy, development, tourism, agrotourism

\section{PENDAHULUAN}

Sektor pariwisata sebagai kegiatan perekonomian telah menjadi andalan potensial dan prioritas pengembangan untuk meningkatkan perekonomian negara. Hampir semua negara menjadikan pariwisata sebagai salah satu sumber penghasilan devisa negara dengan mengendalikan potensi yang ada. Tidak terkecuali Indonesia, perkembangan pariwisata terus bertumbuh dan berkembang menjadi salah satu sektor yang berperan penting dalam perekonomian
Indonesia. Oleh karena itu, pariwisata harus dikelola dengan sangat bijaksana. Perkembangan di dunia pariwisata ini sesuai dengan Instruksi Presiden Republik Indonesia No.9 tahun 1990 tentang perkembangan pariwisata, khususnya Bab II pasal 3 yang menyebutkan, "Usaha-usaha pengembangan pariwisata di Indonesia bersifat suatu pengembangan industri pariwisata dan merupakan bagian dari usaha pengembangan serta kesejahteraan masyarakat dan negara". Pengembangan usaha pariwisata dapat dilakukan dengan 
cara mengembangkan objek dan daya tarik wisata.

Menurut UU No. 10 Tahun 2009 Tentang Kepariwisataan, "Daya tarik wisata adalah segala sesuatu yang memiliki keunikan, keindahan, dan nilai yang berupa keanekaragaman kekayaan alam, budaya, dan hasil buatan manusia yang menjadi sasaran atau tujuan kunjungan wisatawan". Menurut Cooper (2005) menyatakan bahwa,

"Terdapat 4 komponen yang harus dimiliki oleh sebuah sumber daya tarik wisata yaitu: (1) pertama atraksi (attractions), seperti alam yang menarik, kebudayaan daerah yang menawan dan seni pertunjukan; (2) kedua, aksesibilititas (accessibilities), seperti transportasi lokal dan adanya terminal; (3) ketiga, amenitas atau fasilitas (amenities), seperti tersedianya akomodasi, rumah makan, dan agen perjalanan; (4) keempat, anchillary service yaitu organisasi kepariwisataan yang dibutuhkan untuk pelayanan wisatawan seperti organisasi manajemen pemasaran wisata".

Perkembangan daya tarik wisata di Indonesia sudah dilakukan diberbagai provinsi, salah satunya yaitu Provinsi Sumatera Barat. Provinsi Sumatera Barat yang banyak memiliki potensi objek wisata yang layak untuk dikembangkan yaitu Kota Padang, khususnya daerah Agrowisata Lubuk Minturun Padang.
Berdasarkan observasi awal penulis di Agrowisata Lubuk Minturun Padang, penulis menemukan beberapa permasalahan terkait dengan pengembangan Agrowisata Balai Benih Induk Lubuk Minturun Padang. Permasalahan yang pertama yaitu kurangnya atraksi wisata yang ditawarkan oleh agrowisata seperti belum terdapatnya jasa hiburan dan aktivitas rekreasi di wahana agrowisata. Permasalahan kedua yaitu cafetaria dan rumah makan di agrowisata belum dioperasikan dan belum dimanfaatkan sebagai fasilitas restoran. Hal tersebut dapat dilihat dari belum adanya makanan yang dihidangkan di cafetaria ini sehingga wisatawan kesulitan untuk mendapatkan makanan dan minuman.

Permasalahan yang ketiga yaitu kondisi kolam terapi di agrowisata tidak terawat, banyak rumput liar yang tumbuh disekitar kolam, serta tidak ada ikan di kolam tersebut, sehingga wisatawan tidak dapat melakukan aktivitas terapi di kolam tersebut. Masalah keempat yaitu kurangnya pelaksanaan kegiatan di ruang pertemuan agrowisata seperti belum terdapat event workshop dan seminar. Ruang pertemuan tersebut hanya digunakan untuk acara rapat dan pertemuan antara pengelola agrowisata. Masalah kelima yaitu belum terdapat pertunjukan seni dan teater di gazebo atau familiar juga disebut dengan pendopo. Gazebo ini hanya digunakan sebagai tempat 
beristirahat dan diskusi oleh pengunjung agrowisata. Permasalahan keenam yaitu belum terdapat souvenir atau cendera mata yang beragam di Agrowisata ini. Agrowisata BBI hanya menjual tanaman hias yang dijadikan sebagai souvenir, sehingga wisatawan tidak dapat menemukan cendera mata yang beragam untuk dijadikan sebagai kenang-kenangan.

Permasalahan yang telah diuraikan di atas menjadi hambatan pelaksanaan kegiatan pariwisata di Agrowisata Balai Benih Induk Lubuk Minturun Padang, sehingga wisatawan masih enggan untuk mengunjungi agrowisata ini.

Berdasarkan permasalahan diatas, maka tujuan penelitian ini adalah untuk menentukan strategi pengembangan daya tarik wisata di Agrowisata Balai Benih Induk Lubuk Minturun Padang melalui faktor internal dan eksternal.

\section{METODOLOGI PENELITIAN}

Jenis Penelitian ini adalah penelitian deskriptif dengan data kualitatif. Jenis data pada penelitian ini adalah data primer dan sekunder. Sumber data/informan dalam penelitian ini adalah pengelola agrowisata sebanyak 3 orang, masyarakat sebanyak 3 orang serta wisatawan sebanyak 4 orang.

Teknik pengambilan sampel yaitu dengan menggunakan purposive sampling dan snowball sampling. Alat yang digunakan untuk pengumpulan data pada penelitian ini yaitu pedoman wawancara, panduan observasi dan pengambilan dokumentasi. Teknik analisis data dengan menggunakan reduksi data, penyajian data dan pengambilan kesimpulan. Alat analisis data dengan menggunakan analisis SWOT.

\section{HASIL PENELITIAN DAN \\ PEMBAHASAN}

\section{Hasil Penelitian}

1. Atraksi Wisata (Attraction)

a. Sumber-sumber alam

Berdasarkan hasil wawancara peneliti dengan Staff Teknis UPTD BBI tanggal 24 Mei 2017, informan A02 menyatakan,

"Kekuatan dari sumber-sumber alam di Agrowisata Balai Benih Induk Lubuk Minturun Padang yaitu lahan agrowisata seluas $10 \mathrm{Ha}$ yang telah dijadikan vertikal garden, wahana ikan, wahana hidroponik, wahana tanaman hias, wahana tanaman buah, wahana tanaman sayur serta wahana tanaman obat. Semua sumber-sumber alam ini menjadi ciri khas wisata di agrowisata ini karena pengunjung dapat menikmati keindahan wahana tersebut sekaligus menjadi wahana edukasi bagi pengunjung. Kelemahan dari sumber-sumber alam di agrowisata ini yaitu koleksi pada wahana-wahana di agrowisataini belum banyak. Ada beberapa tanaman-tanaman langka, tapi masih sedikit karena SDM tidak mencukupi untuk membudidayakan tanamantanaman tersebut. Peluang yang bisa dimanfaatkan untuk mengembangkan sumber-sumber alam di agrowisata ini yaitu menambah kegiatankegiatan dan aktivitas rekreasi pada 
sumber-sumber alam yang telah tersedia di agrowisata, seperti memberi makan ikan, dan melakukan pencangkokan tanaman, menambah aktivitas-aktivitas rekreasi serta membuat mini garden sehingga dapat menarik wisatawan untuk berkunjung. Selain itu, peluang yang dapat dimanfaatkan yaitu adanya izin dari DPRD untuk menetapkan tarif masuk ke Agrowisata BBI Lubuk Minturun. Ancaman yang mungkin akan timbul yaitu adanya masyarakat yang melakukan aksi pemalakan seperti meminta bayaran parkir kepada pengunjung Agrowisata”.

\section{b. Menanam Bibit Tanaman}

Berdasarkan hasil wawancara dengan Kasi Pengembangan dan Pelestarian UPTD BBI tanggal 24 Mei 2017, informan

A02 menyatakan bahwa,

"Kekuatan dari kegiatan menanam bibit tanaman di Agrowisata BBI Lubuk Minturun adalah memberikan edukasi kepada pengunjung tentang cara membudidayakan tanaman serta dapat mengaplikasikan sendiri di rumah masing-masing. Sedangkan kelemahan dalam melakukan kegiatan menanam bibit tanaman ini yaitu kurangnya SDM dan staff teknis yang memandu kegiatan wisata, sehingga kegiatan ini tidak selalu bisa dilakukan. Peluang yang bisa dimanfaatkan untuk mengembangkan kegiatan menanam bibit tanaman adalah dengan adanya izin dari DPRD untuk memungut biaya masuk ke Agrowisata sehingga dapat menambah staff guide pariwisata. Ancaman yang mungkin akana timbul yaitu adanya pengunjung yang tidak mematuhi peraturan Agrowisata seperti membuang sampah sembarangan dan mengambil koleksi pertanian".

\section{c. Event}

Berdasarkan hasil wawancara dengan informan A01, menyatakan bahwa,

"Kegiatan event di agrowisata belum di banyak karena kegiatan tersebut hanya dilakukan oleh instansi lain, bukan dari pihak agrowisata sendiri. Peluang yang bisa dimanfaatkan untuk mengembangkan kegiatan event di agrowisata BBI yaitu dengan adanya kerja sama dengan instansi lain untuk mengadakan berbagai macam acara sehingga agrowisata lebih banyak dikujungi oleh wisatawan. Ancaman yang mungkin akan timbul yaitu adanya masyarakat yang melakukan aksi meminta bayaran parkir kepada pengunjung Agrowisata".

\section{Fasilitas Wisata (Amenities)}

a. Kafetaria

Berdasarkan hasil wawancara peneliti dengan Kasi Tata Usaha UPTD BBI tanggal 24 Mei 2017, informan A03 menyatakan bahwa,

"Kekuatan dari kafetaria di Agrowisata BBI yaitu adanya pemandangan alam yang indah serta dekorasi ruangan yang unik dengan tema wooden.Sedangkan kelemahan dari kafetaria di agrowisata ini yaitu belum dioperasionalkan secara terusmenerus karena jumlah kunjungan wisatawan masih sedikit. Peluang yang bisa dimanfaatkan yaitu adanya izin dari DPRD untuk memungut tarif masuk ke Agrowisata serta adanya permintaan pengunjung untuk membuka kafetaria setiap hari. Ancaman yang mungkin akan timbul yaitu adanya masyarakat yang 
meminta bayaran parkir kepada pengunjung Agrowisata”.

b. Kolam terapi ikan

Berdasarkan wawancara peneliti dengan pengunjung Agrowisata BBI tanggal 21 Mei 2017, informan C01 menyatakan bahwa,

"Kolam terapi ikan di agrowisata berpotensi untuk dijadikan wahana kesehatan, namun saat ini kolam terapi ikan tersebut belum dimanfaatkan secara maksimal dan kurang terawat, banyak rumput liar yang tumbuh disekitar kolam serta cat kolam yang sudah mengelupas. Peluang yang bisa dimanfaatkan untuk mengembangkan kolam terapi ikan ini yaitu dengan mengadakan kerja sama dengan instansi lain serta adanya izin dari DPRD untuk menetapkan tarif masuk ke agrowisata sehingga pengembangan agrowisata tidak hanya menggunakan dana APBD. Ancaman yang mungkin akan timbul yaitu adanya masyarakat yang memancing ikan di kolam ini karena keamanan agrowisata masih sangat minim".

\section{c. Ruang pertemuan}

Berdasarkan hasil wawancara dengan

Staff Teknis UPTD BBI tanggal 24 Mei 2017, informan A02 menyatakan bahwa:

"Kegiatan ruang pertemuan di agrowisata ini masih sangat sedikit karena acara yang dilakukan di ruang pertemuan ini dilakukan oleh instansi lain. peluang untuk mengembangkan ruang pertemuan ini yaitu dengan adanya kerja sama antara pengelola, pemerintah, dan instansi lain untuk mengadakan berbagai macam kegiatan di ruang pertemuan agrowisata sehingga ruang pertemuan tersebut dapat dimanfaatkan secara mksimal. Ancaman yang mungkin akan timbul yaitu adanya masyarakat yang meminta bayaran parkir kepada pengunjung saat ada event di ruang pertemuan ini”.

\section{d. Gazebo}

Berdasarkan hasil wawancara dengan Kasi Pengembangan dan Pelestarian UPTD BBI tanggal 24 Mei 2017, informan A01 menyatakan bahwa,

"Gazebo di agrowisata dapat dimanfaatkan untuk tempat istirahat bagi pengunjung agrowisata serta dijadikan sebagai tempat untuk berdiskusi oleh pelajar yang berkunjung ke agrowisata ini. Kelemahan dari gazebo ini yaitu belum bisa dikomersialkan karena belum adanya izin dari DPRD untuk menetapkan tarif masuk ke Agrowisata ini. Peluang yang bisa dimanfaatkan untuk mengembangkan gazebo ini yaitu adanya permintaan dari pengunjung untuk menyediakan fasilitas free wifi sehingga pengunjung lebih betah untuk berlama-lama di Agrowisata ini. Ancaman yang mungkin akan timbul yaitu adanya pengunjung yang tidak mematuhi peraturan di Agrowisata seperti membuang sampah sembarangan".

\section{Jasa Pendukung Pariwisata (Anchillary} Service)

a. Cendera mata

Berdasarkan hasil wawancara dengan Kasi Tata Usaha UPTD BBI tanggal 24 Mei 2017, informan A03 menyatakan bahwa, 
"Cendera mata yang ditawarkan di agrowisata BBI Lubuk Minturun Padang masih sangat terbatas, yaitu hanya menyediakan koleksi tanaman hias untuk dijadikan cendera mata. Cendera mata tersebut memiliki peluang yang besar untuk dikembangkan dengan adanya izin dari DPRD untuk menetapkan tarif masuk ke Agrowisata serta adanya permintaan dari masyarakat untuk menyediakan cendera mata yang beragam. Ancaman yang mungkin akan timbul yaitu adanya masyarakat yang memproduksi cendera mata yang sama dengan Agrowisata BBI".

Berdasarkan hasil penelitian dilapangan dengan menggunakan metode wawancara dan observasi maka analisis dan strategi yang dapat dilakukan untuk mengembangkan daya tarik wisata di Agrowisata Balai Benih Induk Lubuk Minturun Padang dapat menggunakan tabel matrik SWOT.

\section{Pembahasan}

Atraksi wisata yang dikembangkan dengan adanya potensi lahan yang luas yaitu sekitar $10 \mathrm{Ha}$ dan pemandangan alam yang indah. Lahan tersebut dapat dimanfaatkan untuk menyediakan wahana permainan dan mini garden serta area camping ground sehingga wisatawan lebih betah untuk berlama-lama di Agrowisata ini. Hal ini sesuai dengan pendapat Pradikta (2013: 54), “Kekuatan objek wisata yang dapat dikembangkan adalah berupa panorama alam yang indah, sumber air yang melimpah serta kondisi objek wisata yang memberi kenyamanan".

Disamping itu, fasilitas wisata di agrowisata BBI yang sudah tersedia seperti ruang pertemuan, kafetaria dan gazebo saat ini masih belum dimanfaatkan secara maksimal. Fasilitas kafetaria belum di operasionalkan setiap hari, ruang pertemuan pun belum dimanfaatkan secara komersial. Fasilitas-fasilitas tersebut memiliki potensi untuk dikembangkan seperti fasilitas ruang pertemuan di agrowisata dapat dimanfaatkan untuk mengadakan event MICE seperti mengadakan acara rapat, seminar, workshop, pameran hasil pertanian, perkumpulan arisan, dan lain sebagainya. Fasilitas kafetaria dapat dioperasionalkan secara continue dengan menyediakan menu-menu yang unik sehingga menjadi daya tarik kunjungan wisatawan dengan adanya aktivitasaktivitas tersebut. Hal ini sesuai dengan pendapat Hadinoto (1996: 18), "Ciri-ciri objek wisata yaitu adanya sumber alam, sumber budaya, aktivitas rekreasi, event, serta aktivitas spesifik, serta adanya daya tarik psikologis". 
Tabel 1. Formulasi Pengembangan Daya Tarik Wisata di Agrowisata Lubuk Minturun Padang Menggunakan Matriks SWOT

\begin{tabular}{|c|c|c|}
\hline \multirow{2}{*}{ IFAS } & STRENGTH (S) & WEAKNESS (W) \\
\hline & $\begin{array}{l}\text { 1. Lahan yang belum } \\
\text { dimanfaatkan secara } \\
\text { maksimal masih luas. } \\
\text { 2. Pemandangan alam yang } \\
\text { indah dan menarik seperti } \\
\text { adanya wahana tanaman } \\
\text { hias, wahana ikan,wahana } \\
\text { hidroponik dan sebagainya. } \\
\text { 3. Menjadi objek wisata } \\
\text { edukasi bagi wisatawan. } \\
\text { 4. Adanya fasilitas penunjang } \\
\text { kegiatan wisata seperti } \\
\text { ruang pertemuan, gazebo, } \\
\text { dan cafetaria yang } \\
\text { menunjang kegiatan wisata } \\
\text { terutama kegiatan event. } \\
\text { Menyediakan berbagai } \\
\text { macam koleksi pertanian } \\
\text { yang bisa dijadikan cendera } \\
\text { mata. }\end{array}$ & $\begin{array}{l}\text { 1. Kurangnya SDM yang } \\
\text { profesional di agrowisata } \\
\text { terutama guide pariwisata. } \\
\text { 2. Adanya sumber daya alam } \\
\text { yang belum dimanfaatkan } \\
\text { dan kurang terawat. } \\
\text { 3. Terbatasnya dana APBD } \\
\text { dan APBN. } \\
\text { 4. Fasilitas wisata di } \\
\text { Agrowisata belum } \\
\text { dimanfaatkan secara } \\
\text { maksimal. } \\
\text { 5. Belum terdapat event yang } \\
\text { dilakukan secara continue } \\
\text { di Agrowisata BBI Lubuk } \\
\text { Minturun. } \\
\text { 6. Belum tersedia produk } \\
\text { cendera mata yang unik, } \\
\text { kreatif dan beragam di } \\
\text { agrowisata. }\end{array}$ \\
\hline OPPORTUNITY (O) & $\begin{array}{c}\text { STRATEGI SO } \\
\text { 1. Mengoptimalkan fungsi }\end{array}$ & $\begin{array}{r}\text { STRATEGI WO } \\
\text { 1. Memanfaatkan dana }\end{array}$ \\
\hline $\begin{array}{l}\text { 1. Adanya izin dari } \\
\text { DPR untuk } \\
\text { menetapkan tarif } \\
\text { masuk dan } \\
\text { melakukan kegiatan } \\
\text { event di Agrowisata. } \\
\text { 2. Mengadakan } \\
\text { pelatihan staff teknis } \\
\text { dan guide pariwisata. } \\
\text { 3. Menambah aktivitas- } \\
\text { aktivitas rekreasi. } \\
\text { 4. Memperbanyak } \\
\text { kegiatan event di } \\
\text { Agrowisata. } \\
\text { 5. Melakukan kerja } \\
\text { sama antara } \\
\text { pengelola, } \\
\text { pemerintah, pihak } \\
\text { swasta, dan instansi } \\
\text { lain untuk } \\
\text { mengembangkan }\end{array}$ & $\begin{array}{l}\text { lahan untuk } \\
\text { mengembangkan aktivitas } \\
\text { wisata. } \\
\text { 2. Memanfaatkan ruang } \\
\text { pertemuan dan gazebo untuk } \\
\text { mengadakan even indoor } \\
\text { dan outdoor dan } \\
\text { meningkatkan kunjungan } \\
\text { wisatawan. } \\
\text { 3. Menyediakan ikan terapi di } \\
\text { kolam terapi ikan untuk } \\
\text { menjadi wahana kesehatan } \\
\text { bagi pengunjung dan } \\
\text { menarik minat kunjungan } \\
\text { wisatawan. } \\
\text { 4. Memanfaatkan kolam ikan } \\
\text { di agrowisata untuk } \\
\text { mengadakan acara lomba } \\
\text { pancing ikan setiap akhir } \\
\text { pekan. } \\
\text { 5. Memanfaatkan tanaman hias }\end{array}$ & $\begin{array}{l}\text { aggaran dari APBD dan } \\
\text { APBN untuk } \\
\text { meningkatkan melakukan } \\
\text { pelatihan guide pariwisata. } \\
\text { 2. Meningkatkan kualitas } \\
\text { SDM dan SDA di } \\
\text { Agrowisata sehingga bisa } \\
\text { dikomersialkan. } \\
\text { 3. Memperbanyak kegiatan } \\
\text { event indoor dan outdoor } \\
\text { ssecara continue baik dari } \\
\text { pihak pemerintah, swasta } \\
\text { maupun insatansi lain. } \\
\text { 4. Memaksimalkan } \\
\text { pengelolaan fasilitas } \\
\text { wisata di agrowisata. } \\
\text { 5. Memperbanyak koleksi } \\
\text { pertanian sehingga } \\
\text { agrowisata tidak monoton } \\
\text { dan dapat meningkatkan } \\
\text { kunjungan wisatawan. }\end{array}$ \\
\hline
\end{tabular}


kawasan wisata edukasi agrowisata.

6. Membuat souvenir yang khas dan unik. sebagai souvenir atau

kenang-kenangan bagi wisatawan yang berkunjung.

6. Pihak pengelola agrowisata yang terdiri dari 6 SKPD harus lebih memperhatikan pengembangan daya tarik wisata di agrowisata dengan cara melakukan promosi dan kerja sama dengan pihak swasta, instansi terkait, serta masyarakat sekitar.

\section{STRATEGI ST}

1. Mengajak masyarakat sekitar untuk ikut andil dan berperan aktif dalam mengembangkan daya tarik wisata agrowisata.

2. Meningkatkan kesadaran peduli alam kepada wisatawan dengan membuat peraturan-peraturan dan mengadakan pelatihan.
6. Membuat souvenir khas agrowisata dengan memanfaatkan koleksi pertanian.
TREATH (T)

\section{STRATEGI WT}

1. Melakukan program pelatihan dan pembentukan kelompok sadar wisata agar pengelola dan masyarakat dapat bersama menjaga keamanan, ketertiban dan mengkondisikan kegiatan wisatawan selama berada di agrowisata.

2. Pihak pengelola harus gencar dalam melakukan penggalangan dana untuk mengembangkan daya tarik wisata di agrowisata.

3. Memberikan pelayanan prima kepada pengunjung dengan melakukan pelatihan tour guide kepada pengelola dan masyarakat sekitar agrowiata.
Agrowisata BBI juga memiliki poteni untuk mengembangkan cendera mata di agrowisata ini. Saat ini cendera mata masih sangat terbatas yaitu hanya menyediakan tanaman hias dan beberapa bibit tanaman lainnya untuk dijadikan cendera mata oleh pengunjung. Cendera mata ini berpotensi untuk dikembangkan dengan menyediakan produk kreatif dengan memanfaatkan koleksi-koleksi pertanian di agrowisata seperti membuat gantungan kunci dari miniatur agrowisata, membuat tanaman bonsai dalam pot kecil, serta menanam tanaman dalam botol dari teknik kultur dan jaringan untuk dijadikan souvenir khas agrowisata, sehingga ada sesuatu yang bisa dijadikan kenang-kenangan oleh 
wisatawan yang berkunjung ke Agrowisata. Hal ini sesuai dengan pendapat Mayani (1991: 11), "Syarat objek wisata yaitu harus memiliki what to buy yaitu seseatu yang bisa dibeli oleh wisatawan seperti souvenir, makanan khas daerah, serta kerajinan tangan masyarakat daerah".

\section{SIMPULAN DAN SARAN}

1. Simpulan

a. Faktor internal pengembangan daya tarik wisata di Agrowisata Balai Benih Induk Lubuk Minturun Padang kekuatannya yaitu berupa pemandangan alam yang indah, memiliki lahan yang luas, serta adanya fasilitas penunjang kegiatan. Kelemahannya yaitu terbatasnya dana, kurangnya staff guide pariwisata serta sedikitnya koleksikoleksi pertanian Agrowisata BBI Lubuk Minturun.

b. Faktor eksternal pengembangan daya tarik wisata di Agrowisata Balai Benih Induk Lubuk Minturun Padang peluang yang bisa dimanfaatkan yaitu adanya izin dari DPRD untuk menetapkan tarif masuk dan melaksanakan kegiatan di Agrowisata BBI, adanya permintaan dari pengunjung untuk mengembangkan fasilitas wisata di agrowisata serta adanya permintaan dari masyarakat untuk bekerja sama dalam mengembangkan daya tarik wisata di agrowisata. sedangkan ancaman yang mungkin akan timbul yaitu adanya aksi masyarakat yang melakukan pemalakan atau meminta bayaran parkir kepada pengunjung serta adanya pengunjung yang tidak mematuhi peraturan di agrowisata seperti membuang sampah sembarangan.

c. Strategi pengembangan yang dapat dilakukan untuk mengembangkan daya tarik wisata di Agrowisata BBI yaitu 1) Memanfaatkan lahan yang luas untuk menambah atraksi wisata seperti menyediakan wahana permainan dan aktivitas rekreasi di agrowisata. 2) Memanfaatkan fasilitas wisata seperti ruang pertemuan dan gazebo untuk mengadakan berbagai macam acara seperti event MICE, dan memanfaatkan kolam terapi ikan dan kafetaria untuk menarik minat kunjungan wisatawan.

Menyediakan berbagai macam cendera mata dengan memanfaatkan teknik kultur dan jaringan.

2. Saran

Dinas Pengelola Agrowisata BBI Lubuk Minturun diharapkan dapat 
merealisasikan strategi pengembangan daya tarik wisata berupa atraksi wisata, fasilitas wisata serta jasa pendukung pariwisata. Bagi masyarakat agar bisa berperan aktif dan ikut andil dalam mengembangkan daya tarik wisata di agrowisata BBI. Sementara itu, pihak swasta, pelaku bisnis dan instansi lain agar dapat berinvestasi dengan melakukan berbagai macam acara atau event-event tertentu di Agrowisata BBI. Bagi Fakultas Pariwisata dan Perhotelan agar dapat menerapkan pengabdian masyarakat melalui penyuluhan dalam pengembangan objek wisata. Bagi peneliti berikutnya agar dapat lebih dalam lagi meneliti tentang daya tarik wisata di agrowisata dengan menggunakan metode balance score card.

\section{DAFTAR PUSTAKA}

Cooper, Criss. 2005. Tourism: Principles and Practice, Third Edition. England: Pearson Education Ltd.

Hadinoto, Kusudianto. 1996. Perencanaan Pengembangan Destinasi Pariwisata. Jakarta: Universitas Indonesia Press.

Maryani, E. 1991. Pengantar Geografi Pariwisata. Bandung: IKIP

Pradikta, Angga. 2013. Strategi Pengembangan Obyek Wisata Waduk Gunung Rowo Indah Dalam Upaya Meningkatkan Pendapatan
Asli Daerah (PAD) Kabupaten Pati. Skripsi. Semarang: Universitas Semarang.

Rangkuti, Freddy. 2011. SWOT Balanced Scorecard. Jakarta: Gramedia Pustaka Utama

Undang-Undang No. 9 Tahun 1990. Tentang Kepariwisata. 